\title{
OPEN
}

\section{Author Correction: Inhibition of casein kinase $1 \delta /$ / improves cognitive-affective behavior and reduces amyloid load in the APP-PS1 mouse model of Alzheimer's disease}

\section{S. Sundaram, S. Nagaraj, H. Mahoney, A. Portugues, W. Li, K. Millsaps, J. Faulkner, A. Yunus, C. Burns, C. Bloom, M. Said, L. Pinto, S. Azam, M. Flores, A. Henriksen, J. Gamsby \& D. Gulick (iD \\ Correction to: Scientific Reports https://doi.org/10.1038/s41598-019-50197-x, published online 24 September 2019}

The Acknowledgements section in this Article is incomplete.

"This work was made possible by a grant from the Florida Department of Health (7AZ13; DG) and by stipends from the Morsani College of Medicine Research, Innovation \& Scholarly Endeavors Office (SD; SN)."

should read:

“This work was made possible by grants from the Florida Department of Health (7AZ13, DG; 7AZ24 and 9AZ31, JG), Alzheimer's Association (2016-NIRG-393975, JG) and by stipends from the Morsani College of Medicine Research, Innovation \& Scholarly Endeavors Office (SS; SN)."

\begin{abstract}
(c) (i) Open Access This article is licensed under a Creative Commons Attribution 4.0 International License, which permits use, sharing, adaptation, distribution and reproduction in any medium or format, as long as you give appropriate credit to the original author(s) and the source, provide a link to the Creative Commons license, and indicate if changes were made. The images or other third party material in this article are included in the article's Creative Commons license, unless indicated otherwise in a credit line to the material. If material is not included in the article's Creative Commons license and your intended use is not permitted by statutory regulation or exceeds the permitted use, you will need to obtain permission directly from the copyright holder. To view a copy of this license, visit http://creativecommons.org/licenses/by/4.0/.
\end{abstract}

(c) The Author(s) 2019 